\title{
Study of Halal Food Export Policy in Indonesia
}

\author{
N Masruroh ${ }^{1}$ \\ State Islamic University of Jember ${ }^{1}$ \\ \{nikmatul.masruroh82@iain-jember.ac.id ${ }^{1}$ \}
}

\begin{abstract}
Indonesia, as the biggest Muslim country, has not been played a significant role in halal food exports, as indicated by its position in halal food exports. Indonesian's halal food industry has not reached the top 10 countries that include Saudi Arabia, Malaysia, Brazil, Oman, Jordan, Australia, Brunei Darussalam, Pakistan, Sudan, and Qatar. Nowadays, Indonesia is the biggest country in halal food import with a value of 170 billion USD or equal to Rp.2.465 billion (at exchange rate Rp. 14.500). The data showed that Indonesia is in the first rank of the 10 countries with the largest amount of halal food expenditure in the world. This is so unfortunate for Indonesian, which has the largest Muslim population in the world. Researches on Indonesian's position in halal food exports are still very limited and some of them focused only on the country's quantity exports and imports. The potential of halal food production in Indonesia is huge and it needs careful studies on the influence of halal food export policy. This research aims to examine the conditions that lead to the limited role of Indonesia in halal food exports. Using library research, this paper will explore the halal export policy in Indonesia, hoping to bring the competitiveness of the country's halal foods in the international market. This research found that Indonesia's halal food exports today have been able to grow only in some countries with similar cultures. Some aspects that influence halal food export policy in Indonesia are lack of legal implementation in halal foods, complicated policy bureaucracy, minimal labeling of halal foods for the producers. The research result also suggested that Indonesia needs a commitment to rearrange a new resolution model of halal food export policy in forms of deregulation and de-bureaucratization.
\end{abstract}

Keywords: Halal Foods, Export Policy, Indonesia

\section{Introduction}

Indonesia, as the largest Muslim country, has been able to play a role in halal food exports. According to the GIEI report, in 2018/2019, sharia-based industries in Indonesia have ranked $11^{\text {th }}$ out of 15 countries that were surveyed based on GIEI indicators. The $11^{\text {th }}$ position was driven by the halal food industry. The industry of foods and beverages as a whole is driving the growth of GDP until 34\% (based on BPS and the Data by the Ministry of Industry). It explained that the Indonesian halal food industry has not been able to reach the top 10 ranks that include Saudia 
Arabia, Malaysia, Brazil, Oman, Jordan, Australia, Brunei Darussalam, Pakistan, Sudan and Qatar [1].

Instead of exporting halal foods, actually, Indonesia spends 170 billion US dollars on halal food products or equivalent to Rp. 2,465 trillion (with an exchange rate of 14.500 per dollar) [2]. The following table listed the 10 countries that have the highest expenditure in the halal food sector:

Table 1.The Highest Expenditure in the Halal Food Sector

\begin{tabular}{cccc}
\hline Number & Country & $\begin{array}{c}\text { Halal food sector expenditure (US } \\
\text { Dollar) }\end{array}$ & $\begin{array}{c}\text { Halal food sector } \\
\text { expenditure (Rupiah) }\end{array}$ \\
\hline 1 & Indonesia & US\$ 170 Bn & Rp. 2.465 trilion \\
2 & Turkey & US\$127 Bn & Rp. $1.841,5$ trillion \\
3 & Pakistan & US\$ 118 Bn & Rp. 1.711 trilion \\
4 & Egypt & US\$ 86 Bn & Rp. 1.247 trillion \\
5 & Bangladesh & US\$ 76 Bn & Rp. 1.102 trilion \\
6 & Iran & US\$ 63 Bn & Rp. 913,5 billion \\
7 & Saudi Arabia & US\$ 51 Bn & Rp. 739,5 billion \\
8 & Nigeria & US\$ 47 Bn & Rp. 681,5 billion \\
9 & Russia & US\$ 41 Bn & Rp. 594,5 billion \\
10 & India & US\$ 38 Bn & Rp. 551 billion \\
\hline
\end{tabular}

Source: from Global Islamic Index 2018/2019

The data showed that Indonesia is in the first position of 10 countries with the largest amount of halal food expenditure in the world. This phenomenon is, of course, detrimental to the Indonesian nation given that it has the largest Muslim population in the world, i.e. about 215 million Muslims or 13\% of the world's Muslim population (in 2015) [3]. According to the Ministry of Trade Report, Indonesia has imported foods and beverage consumer goods, both processed and unprocessed or raw materials, at a total of US\$ 158.762.449.395. This amount is more than other commodities such as fuel which is only US \$ 4.125.740.064,00 [4]. While the 10 main export commodities carried out by Indonesia were none of the foods, the export commodities included TPT, technology, rubber and rubber products, palm oil, forest products, footwear, automotive, shrimp, cocoa and coffee. Ironically, Indonesia has several potential export commodities that can be developed, such as leathers and leather products, medical equipment, medicinal plants, processed foods, essential oils, fish and fishery products, crafts, jewelry, spices, and office equipment. Indonesia should have been able to play a significant role in export activities, especially halal food exports [5].

A few types of research have been conducted on the position of Indonesia in halal food exports. Research by Acinta Bunga Putri and Suhadak [6] discussed Indonesian exports before and after the trade war. However, this research did not discuss the positioning of Indonesia's halal food exports in international trade.S Mashari and R Nurmalina in their research has only focused on Indonesian trade position for frozen and processed shrimp [7], neglecting Indonesia's position on halal food exports. In addition, among all the researches on halal food none has discussed the position of Indonesia for halal food exports in international market. Some discussed only the 
regulation and the strengthening of halal foods in Indonesia [7]. For example, Edi Kriharyanto's research was more about the regulation and provisions for halal productsin Indonesia. Similar studies havebeen conducted by Haryono, Dwi Iryaning Handyani, in which they talked about halal supply chainsin the context of marketing halal products [7].

In addition, studies on halal foods focused more on consumer behaviors and awareness of halal foods [8]. No research has been conducted on halal product exports related to the position of Indonesia in halal foods exports in international trade.[9], [10]. Some studies have only discussed Indonesia's food export quantity. A study by Suryono, or Harbi [5], [11] explained that Indonesia's export values from 2013 until 2017 were fluctuating but decreased in 2016. The slowdown in exports affected the lower growth of the national economy; this is suitable for Balassa's statement on postcolonial [12] that economic growth is always influenced by the export and import factor [13].

Therefore, there is a need for a careful study on the influence of halal food export policy in Indonesia. This is because Indonesia has a huge potential for halal food production [8] by which the country should have been able to become a center of halal foods in the world like Malaysia [8]. That potential can be seen from the number of the Muslim population in Indonesia, which reached 215 million people. This means that the need for halal foods will be in line with the increasing number of the Muslim population in Indonesia [14].

This paper aims to examine the conditions that have contributed to the limited role of Indonesia in halal food export. Three questions are raised in this paper. The first is to what extent Indonesia is involved in halal food exports. The second is what aspects influenced export policy in Indonesia. The third is how a resolution model for policy halal food exports can be formulated in Indonesia.

\section{Method}

The paper will discuss export halal food policy in Indonesia. It will also shed light on Indonesia's involvement and position in the field of halal food export in International trade. In completing the required data, this paper used a library approach. Library research was used to explore Indonesia's export policy in fostering Indonesia's competitive halal foods in International trade [15].

A descriptive analysis was used in this library research. The data collection method used to obtain information on Indonesia's position in the export of halal food used documentation and literature studies related to the patterns of Indonesia's involvement in halal food exports, the aspects that affect export policy in Indonesia, and the formulation of a resolution model for halal food export policy in Indonesia. The data obtained were analyzed using the descriptive analysis to describe comprehensively about Indonesia's involvement in halal food exports.

\section{Results and Discussion}

\section{The Pattern of Indonesia's Involvement in Halal Food Exports}

In the international trade industry, Indonesia is one of the countries that have an active role in import and export trade. However, in the current free trade, it turns out that many countries do 
protection and use various ways to prevent the entry of Indonesian products. On the national level, Indonesia must also face the invasion of products from abroad which often carry out dumping and unfair trade practices [16].

Indonesia's involvement in the world's trade is marked by the signing of the FTA (Free Trade Agreement). This is done in order to obtain comparative advantages. The countries that sign this agreement will certainly benefit from the results of trade formation and trade diversion. Due to a new trend in the world's trade, the countries joined in the FTA after which many trade agreements were made to facilitate bilateral and multilateral relations. Bilateral agreements refer to preferential trading arrangements. Conversely, a multilateral agreement is a preferential trading arrangement that involves more than two parties. Until now, Indonesia already has 7 agreements in progress and 8 agreements that are still in the stage of negotiation or further study [17].

Indonesia is incorporated in AFTA and ASEAN, so Indonesia's main export markets are China and ASEAN countries. Even in export competition, Indonesia must compete with ASEAN countries. China, ASEAN countries, Asian countries, and the United States are Indonesia's main destinations because they have cultural and historical similarities. Although there are some differences, trade agreements between these countries can still be fulfilled. Some of Indonesia's export destinations include Japan, China, and Singapore. The three destination countries have their own historical relations.

In addition to the ASEAN countries and China, Indonesia also carries out trade with other countries, such as the WTO (World Trade Organization) as an international organization that was established with enthusiasm among others to facilitate the flow of trade in goods and services manifested by removing various barriers between the member countries, like the United States and India. In reality, each country is still trying to protect its domestic market in competing with imported products through various tariff or non-tariff barriers. In the implementation of international trade, trade barriers can be understood as a form of measures that affect and limit the free flow of goods and services in export and import activities by a country or public organization that is not in line with international rules and standards. Particularly for non-tariff barriers, its application in the world has tended to increase in recent years as a lot of economic cooperation is driving tariff liberalization.

The increasing consumer demand for products that are safe and environmentally friendly also adds to the popularity of non-tariff barriers. Some forms of non-tariff barriers are well known in the trade. Some examples include the import quota, licenses, import restrictions in the form of embargoes, administrative and bureaucratic delays at the border entrance, regulations on standards such as packaging and labeling, and regulations on health and sanitation requirements and quality standards. These obstacles have also been regulated by the WTO through a number of agreements such as the Technical Barriers to Trade (TBT) Agreement, the Sanitary and Phytosanitary Measures (SPS) Agreement. These barriers are commonly referred to as technical barriers to trade.

Both the TBT Agreement and the SPS are structured to ensure technical, sanitary and phytosanitary regulations, standards, testing, and certification procedures are applied to protect consumers or the environment so that they do not become unnecessary obstacles to trade. Until October 2018, more than 130 Indonesian commodities experienced cases of technical trade barriers including fishery products, processed foods, plantations, fat and oil products, wood and wood products, and various other products. The Renewable Energy Directives (RED) policy can be an example of trade technical barriers. The policy currently in the process of amendment is an 
effort by the European Union to prevent palm oil as a raw material for biodiesel. Palm oil, which is a favorite commodity of Indonesia, is increasingly becoming the target of trade technical barriers. If explored further this policy stems from trade competition between palm oil and vegetable oil produced by Europe. Potential technical obstacles in the form of labeling regulations also affect Indonesian food and beverage products. An example is the Chilean Government policy which took effect in June 2016 for labeling food products sold at the end consumer level, with the aim of protecting the health of Chileans from foods containing energy, sodium, total sugar, and saturated fat. If it is found that food products containing energy, sodium, total sugar, and saturated fat are more than the maximum limit, we must add an octagonal image with a size of $20 \%$ of the packaging of food products.

From Indonesia's involvement in international trade, it can be seen that one of the protections that can prevent Indonesian products from competing with other countries is the labeling problem, as one of the guarantees of the safety of products traded, especially related to food. Some brands of food and beverage products that have been exported by Indonesia and are driving export values include Kopi Kapal Api, silver queen chocolate, kacang dua kelinci, tolak angin, extra joss, kopiko, equil, mariza foods, Indomie, and La Fonte. The commodities are able to become a worldwide brand, so the brand image of the community of these products is foreign products.

The cooperation with OIC countries opens up opportunities for Indonesia to be able to collaborate mainly in the field of trade. In the global market, the halal industry has its own attention, so that the OIC countries have become the target of exporting halal products from other countries. For example processed meat exports from livestock such as chickens, goats, cows, which are the leaders of global exports are Brazil (US $\$ 7$ billion), USA (US $\$ 4.9$ billion), the Netherlands (US \$ 2.5 billion), Poland (US \$ 1.7 billion), France (US $\$ 1.3$ billion), Germany (US \$ 1.3 billion), Belgium (US \$ 1 billion), Hong Kong SAR (US \$ 804 million), Hungary ( US \$ 652 million) and Turkey (US \$ 651 million).

The example gives a sign that the halal food side of the meat sector still relies on Muslim minority countries. This means that Muslim countries are still importers in the halal sector, for example, Saudi Arabia is still the biggest importer of processed foods for seafood and fish. In this case, Indonesia's position is not yet apparent in halal food exports. The pattern of Indonesian involvement is still limited to food and beverage exports, not yet concentrated on halal-certified food and beverage products. Therefore, Indonesia's halal food exports cannot yet occupy a strategic position. Particularly, in OIC countries, such as Saudi Arabia, Egypt, Malaysia, and others Indonesia's position in halal food exports is still inferior when compared to Malaysia through the Section for Kajian Makanan dan Barangan Gunaan Islam Jabatan Kemajuan Islam Malaysia (JAKIM), Singapore through the Islamic Religious Council of Singapore, and Australia through several halal certification bodies. These institutions not only provide certification of halal products but more than that, they also protect, monitor and even intervene in the market of halal products.

Absorption of market share and security for the export of Indonesian halal products is still behind compared to neighboring countries such as Malaysia which reached 13.8\%, United Arab Emirates 13.6\% and Saudi Arabia 12\%. Indonesia ranks fourth with a percentage of $10.7 \%$ for overall exports of halal products. Moreover, the halal food industry is still absorbed by around 3.3 billion US dollars with the aim of going to the OIC countries. Halal food exports increased in 2016 
by 1.02 USD from 944.6 million in 2012 with destination countries Malaysia, Saudi Arabia, United Arab Emirates, Nigeria, and Pakistan. Thus, currently, Indonesian halal food products are still able to penetrate the country's market OIC countries and non-OIC countries that have millions of Muslims, such as France and Britain. Indonesian products are easier to enter OIC countries because they have cultural similarities, especially related to religious patterns. Thus, Indonesia is easier to position its products in Islam-based countries.

\section{The Aspects That Affect the Export Policies of Halal Food in Indonesia}

Indonesia's halal food export position is still not able to occupy the first position in the world; it cannot be separated from the implementation of halal food policy in Indonesia. In Indonesia, the application of halal labeled product obligations has not yet been fully implemented. Although the law on the guarantee of halal products has been passed, and on October 17, 2019, this law was officially enacted, meaning that every business actor must have a halal label on his product. However, until this moment the reverberation of the act has not been apparent or even does not exist at all. Government Regulation No. 31 of 2019, which regulates the implementation of the Act, has not been able to touch halal food producers to lower levels. On one hand, there has been an increase in the certification of halal products from year to year. The following is the LPPOM MUI halal product certification data:

Table 2. Data on Halal Certification by LPPOM MUI

\begin{tabular}{|c|c|c|c|}
\hline YEAR & The Number of Companies & The Number of SH & $\begin{array}{c}\text { The Number of } \\
\text { Products }\end{array}$ \\
\hline 2011 & 4,325 & 4,869 & 39,002 \\
\hline 2012 & 5,829 & 6,157 & 32,890 \\
\hline 2013 & 6,666 & 7,014 & 64,121 \\
\hline 2014 & 10,180 & 10,322 & 68,576 \\
\hline 2015 & 7,940 & 8,676 & 77,256 \\
\hline 2016 & 6,564 & 7,392 & 114,264 \\
\hline 2017 & 7,198 & 8,157 & 127,286 \\
\hline 2018 & 11,249 & 17,398 & 204,222 \\
\hline TOTAL (2011 - 2018) & 59,951 & 69,985 & 727,617 \\
\hline
\end{tabular}

Source: MUI halal product statistic 
From these statistics, the development of halal products in Indonesia has experienced growth on the one hand, but on the other hand, it has not been able to boost the competitiveness of exports of halal products. Indonesia's inability to become an international center for halal food is influenced by the seriousness in the enactment of Law JPH No. 33 of 2014. Actually, the Act was formulated with all forms of ideals, but in reality, it has not been able to be implemented massively and producers' concern for labeling is still limited. According to the Chairman of LPPOM MUI, Lukmanul Hakim, in 2018 still, around 3.5 million companies had not conducted halal certification from a total of 3.6 million companies.

This means that if it will boost competitiveness in the export sector, then the issue of domestic halal certification must be resolved. In addition, the institutional change in the halal certification process is also the cause of the slowing growth rate of halal certification products in Indonesia. Since the enactment of Law No.33 of 2014, the halal certification process is handled by the Ministry of Religious BPJPH, but then the law was amended to restore the MUI halal certification process. This indicates that the legal issues and regulations regarding halal certification have not been resolved. It implies that the halal certification process tends to be convoluted and unclear.

Law socialization also needs to be done so that producers are increasingly aware of halal certification. Some socialization programs and literacy certification of halal products are carried out by LPPOM MUI through several programs. Among others are INDHEX (Indonesia International Halal Expo), Halal Olympics, Halal Food Goes to School, Halal Tourism (Halal Tour), Halal Talkshow Seminar, Halal Competition, Halal Socialization to SMEs/Large Companies, Halal Competition, Facilitation of Free Halal Certification, Halal Socialization through Media and Social Media and Merchandise [18]. The program's implementation has not been able to touch thoroughly the halal awareness among both the consumers and the producers. The literacy has not been able to touch the lowest level, especially in terms of producers, so producers, especially MSMEs do not feel it is important to certify the products they sell.

\section{Formulation of a Resolution Model forHalal Food Export Policy in Indonesia}

The policies related to halal food exports in Indonesia continue to be evaluated along with evaluations on halal certification policies in Indonesia. Deregulation and de-bureaucratization were carried out in the effectiveness of the halal certification process. The deregulation was realized by cutting the halal product certification procedure, initially, the procedure was as follows: 


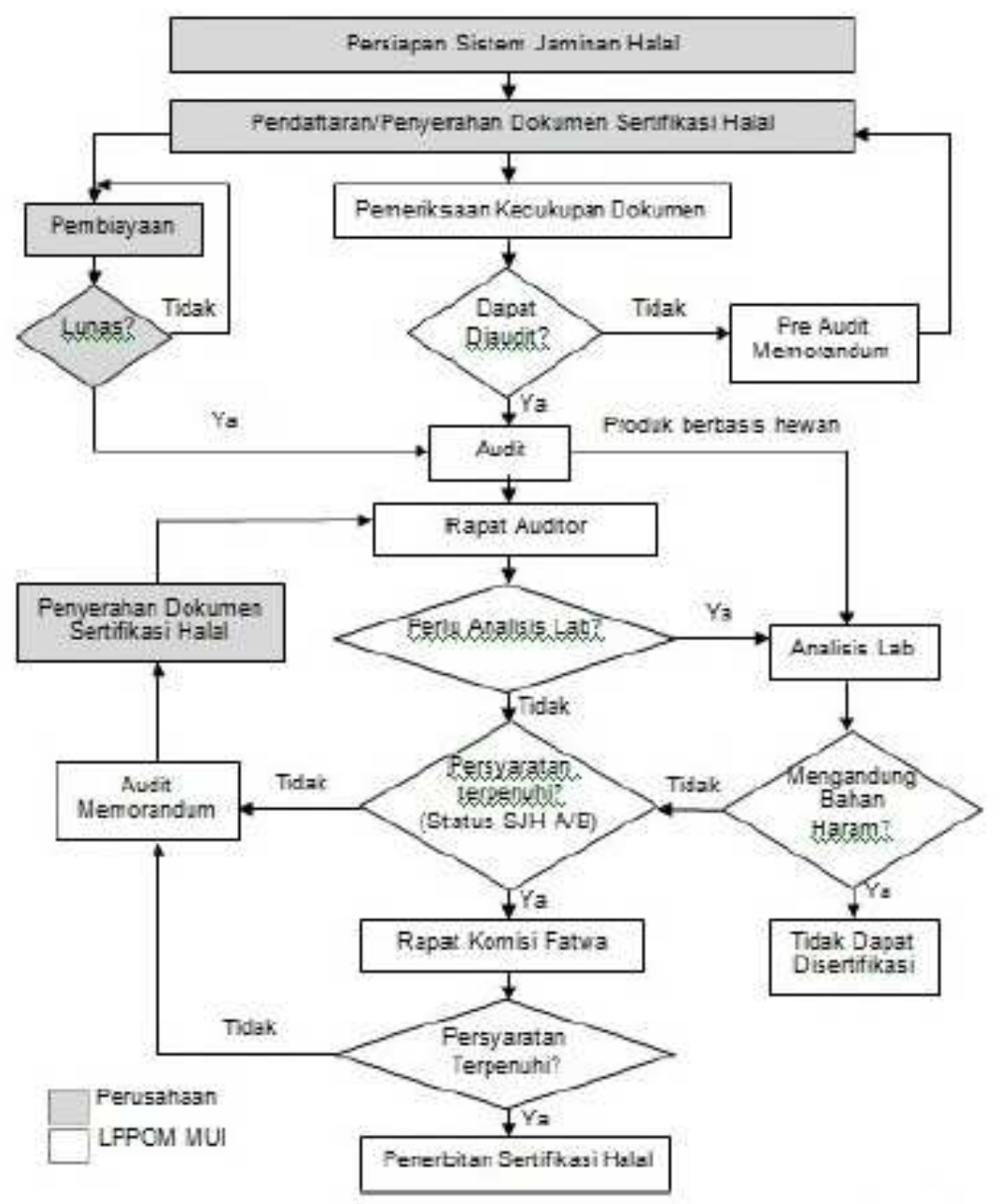

Figure 1. Halal Certification Flow before Law No. 33 of 2014

Source: LPPOM MUI

The process that must be passed by producers to certify halal must go through a long bureaucracy so that by Law No. 33 of 2014 the process was made to be shorter and not convoluted in hopes of more effective and companies that certify halal products is increasing. Following is the flow of halal product certification after Law No. 33 of 2014. 


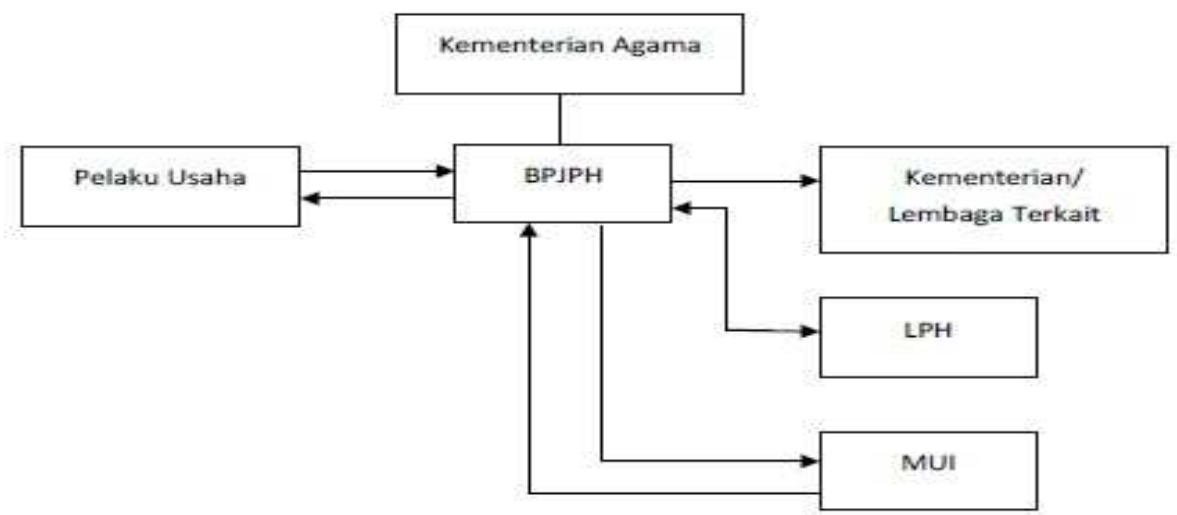

Figure 2. Halal Certification Flow after Law No. 33 of 2014

From the figure above, it is clear that the halal certification process is getting shorter and more straightforward, but unfortunately, it has not been implemented yet. It can be inferred also from this figure that de-bureaucratization is carried out to facilitate the halal certification process by the producers. The process of regulation and bureaucracy, if implemented, can boost the number of halal products. When the domestic halal product certification increases, the performance of Indonesian halal food exports can also reach a higher level.

The formulation of this resolution model is expected to be able to boost Indonesia's halal food export competition. Deregulation and de-bureaucratization require serious follow-up from the policymakers, especially the government so that export competitiveness is able to penetrate the international world market. Of course, regulations and bureaucracy must be continuously improved and shortened so that the effectiveness of the halal certification process can be achieved and Indonesia can realize its ideals as an international halal hub.

\section{Conclusion}

This study provides a preliminary result that Indonesian halal food exports have been currently only able to penetrate the markets of countries that have cultural similarities, whereas countries that have different cultures are difficult to accept Indonesian halal food products. The aspects that affect the policy of halal food exports include the halal food laws that have not yet been implemented, convoluted bureaucratic policies and literacy of halal food labels for producers that are still minimal. Therefore, it is necessary for Indonesia to strengthen its commitment to reformulate a resolution model for halal food exports, such as deregulation and debureaucratization. 


\section{References}

[1] T. Reuters and D. Standard, "An Inclusive Ethical Economy: State of the Global Islamic Economy Report 2018/2019," Dubai, 2018.

[2] J. S. A. Achmad, "Menyongsong Pemberlakuan Kewajiban Sertifikasi Halal di Indonesia," J. Ilm. Living Law, vol. 11, no. 1, p. 1641, doi: (March 18, 2019): 1, https://doi.org/10.30997/jill.v11i1.1641.

[3] W. A. Reni, "Halal Science: An Introduction," J. Halal Res. Accord. Dinar Stand. Anal. from Expend. from Var. Sect., vol. 1, no. 1, 2015.

[4] Kemendag, "Import Development According Commodities and Kind of Goods.".

[5] A. Suryono, "Analisis Ekspor Indonesia ke Negara Tujuan Utama dan Komoditi Utama Tahun 2013 Sampai 2017,” J. Akuntabel, vol. 16, no. 1, pp. 25-30, 2019.

[6] A. B. Putri, "Uji Beda Ekspor dan Impor Sebelum dan Sesudah Terjadi Perang Dagang Amerika Serikat dan China (Studi pada Badan Pusat Statistik Periode September 2017September 2018)," J. Adm. Bisnis, vol. 71, no. 1, p. 10, 2019.

[7] E. Krisharyanto, E. Retnowati, and N. Tri Hastuti, "Regulation and Provisions For Supervision of Halal Product in Indonesia," J. Leg. , Ethical Regul., vol. 22, no. 1, p. 10, 2019.

[8] N. Arinilhaq, "Purchase Intention on Halal Culinary Fast Food In Yogyakarta," J. Ekon. Stud. Pembang., vol. 18, no. 7, 2017.

[9] Erik S. Reinert, "Globalization, Economic Development, and Inequality: An Alternative Perspective," in New Horizons in Institutional and Evolutionary Economics, Cheltenham, UK: Northampton, MA: Edward Elgar, 2007.

[10] Hadiyan and Azman, "Halal Development and Food Exports: Evidence from Malaysia and MEACs:” Globalisasi dan ekspor makanan halal di Malaysia, vol. 7. 2012.

[11] Y. Alharbi, "Halal Food Certification, Regulations, Standards, Practices in the Netherland," in MSc Thesis, 2015, p. 72.

[12] B. Balassa, "Exports and Economic Growth," J. Dev. Econ., vol. 5, pp. 181-189, 1978.

[13] N. Azah Anir, N. M. H. Nizam, and A. Masliyana, "RFID Tag for Halal Food Tracking in Malaysia: Users Perceptions and Opportunities.”.

[14] N. Atalan-Helicke, "The Halal Paradox: Negotiating Identity, Religious Values, and Genetically Engineered Food in Turkey," Agric. Human Values, vol. 32, no. 4, pp. 663740, 2015, doi: https://doi.org/10.1007/s10460-015-9585-z.

[15] T. Mann, The Oxford Guide to Library Research. New York: Oxford University Press, 1998.

[16] Kemenag, "Info Perdagangan Ed 4," 2018.

[17] A. A. Widyasanti, "Perdagangan Bebas Regional dan Daya Saing Ekspor: Kasus Indonesia," Buletin Ekonomi Moneter dan Perbankan, Jakarta, p. 6, 2010.

[18] MUI, "Halal.”. 